\title{
GOSPEL AND SCRIPTURE: RETHINKING CANONICAL UNITY ${ }^{1}$
}

\author{
Francis Watson
}

\begin{abstract}
Summary
It is widely believed that the Christian Bible is merely an anthology of the religious literature of ancient Israel and the early church, and that to speak of its 'unity' or 'coherence' is no longer possible. But biblical unity is still an issue where one seeks to understand the texts in their relation to God, and there are two main ways in which this issue is typically presented: biblical unity may be grounded in the process of divine inspiration which is believed to have generated these writings, or it may be grounded in a theory of providential ordering. The problem with both approaches is that they fail to reflect on the relation between scripture and the gospel, the proclamation of what God has done in and through Jesus and his Spirit which, for Christians, lies at the centre of the testimony of both Old and New Testaments. In his letter to the Galatians, Paul struggles to articulate an evangelical hermeneutic for scriptural interpretation, over against opponents who hold no less 'high' a doctrine of scripture than he does. This evangelical hermeneutic is not simply imposed on the texts from the outside, but identifies fundamental elements in the dynamics of these texts, notably the promise/law polarity. In broad outline, Paul's argument can serve as a model for our own attempts to rethink scriptural unity.
\end{abstract}

\section{Introduction}

Integral to the concept of the scriptural canon is the idea of its 'unity' or 'coherence'. A canon is not an anthology, although, like an anthology, its contents may well have been selected out of a mass of available material. An anthology cannot be held accountable for the unity or coherence of its contents. If the poets appear to disagree with one another, then that simply illustrates the rich diversity of the

1 The Tyndale Biblical Theology Lecture for $\mathrm{AD} 2000$. 
human experience in which a particular poetic tradition is rooted. But to explain the varied content of Christian scripture in this way would be to abandon the concepts of canon and scripture. A richly diverse human experience certainly underlies the writings of Christian scripture; and yet these writings are supposed to speak, from beginning to end, of the one God who is trustworthy and true, and to do so in a way that is itself trustworthy and true. Anthologies and canons are both diverse, but canons also lay claim to some degree of structured coherence, a unifying logic inherent to the writings themselves. Canons are supposed to express something other than the preferences and prejudices of anthologisers.

It is, of course, possible for interpreters of the Bible to understand it as an anthology - or rather, as two anthologies, one earlier and one later. The individual text is then understood without reference to any structured whole, without any sense that the biblical authors, in many and various ways, are all striving to articulate a single though infinitely rich and complex subject-matter. Where the individual biblical texts are interpreted in the context of one or other of two relatively independent anthologies, then the concept of biblical 'unity' will seem highly problematic, an outmoded vestige of a premodern understanding of the Bible. Modernity holds biblical unity to be no longer credible, and postmodernity deems it to be ethically offensive. ${ }^{2}$ Assuming that both are wrong, or, more precisely, that they go wrong in elevating their partial insights into absolute dogmas, it remains an open question how the unity of Christian canonical scripture is to be construed. I shall try to show that certain approaches to biblical unity are inadequate, and that they are inadequate because they are unevangelical - taking the word 'evangelical' to refer not to a particular Christian tradition but to the gospel, which stands over against all Christian traditions as judgement and hope. Yet excessive preoccupation with theological inadequacies would itself be unevangelical, and the major task is therefore a positive and constructive one: to understand biblical unity in the light of the gospel.

2 For Walter Brueggemann, for example, concern for biblical unity is an expression of 'the pervasive Western, Christian propensity to flatten, to refuse ambiguity, to lose density, and to give universalizing closure'-a propensity that may be traced in part to 'the Constantinian establishment of Christianity, whereby the political purpose of the religion is to provide reliable legitimacy for the claims of power, Theology of the Old Testament: Testimony, Dispute, Advocacy (Minneapolis: Fortress, 1997), pp. 81, 82. 
The relation between gospel and scripture is the contentious issue at the heart of Paul's letter to the Galatians, and our reflections on this theme will take the form of an extended paraphrase of parts of this text. The Pauline text that attests the gospel is itself scripture, for the Christian community and perhaps, in some sense, even for Paul himself and for many of his first readers. So there is no question of treating gospel and scripture as two independent entities that must somehow be co-ordinated. What is at stake is the question how and to what extent scripture-as a corpus of writings, both old and new-attests the gospel, and finds its own unity and coherence in doing so.

Where scriptural unity has not fallen victim to modernity or postmodernity, it is often understood along the following lines:

However diverse they may be, the books of the Bible have one thing in common that differentiates them from all other writings, and that is their 'inspiration'. They have their own individual human authors, but they also share in an overarching divine authorship, so that what Jeremiah or John says is also what God says. The Bible is therefore 'the Word of God'. To describe it as such is no more than to repeat its own claim about itself. In the prophetic 'Thus says the Lord', the word of the prophet coincides with the word of God, and in the New Testament this concurrence of divine and human is extended to scripture in its entirety. 'All scripture is inspired by God

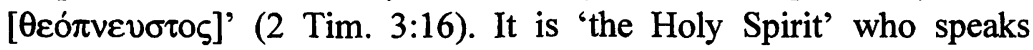
'through the mouth of our father David' in the text of a psalm (Ac. 4:25). Indeed, without denying the reality of human agency, a scriptural text can be introduced with the formula, 'As the Holy Spirit says' (Heb. 3:7); other texts are traced to the utterance of either God (Heb. 1:5-13) or Christ (Heb. 10:5-9). Jesus himself reasserts the divine authority of the Law of Moses, from which not even a single letter will be erased till heaven and earth pass away (Mt. 5:18). When he states that 'scripture cannot be broken' (Jn. 10:35), he confirms that it is his view too that what scripture says God says. And so Jesus ascribes the Genesis narrator's comment about the basis of marriage (Gn. 2:24) not to Moses but to 'the one who from the beginning made them male and female' (Mt. 19:4-6). For Jesus and for the New Testament, 'Thus says the Lord' refers to scripture in its entirety.

On this view, scriptural unity is grounded in a doctrine of inspiration which traces all the scriptural texts back to a single divine authorship. According to this doctrine, scripture is to be interpreted as 
authoritative, as sufficient and as non-contradictory. Scripture is the Word of God, since its utterance is God's utterance; it is the fullest and most immediate expression of the authority of God. Scripture alone is the Word of God, for no other writing or tradition is inspired as it is inspired. As the authoritative and sufficient Word of God, scripture must also be non-contradictory. It is as unthinkable that scripture should contradict itself as that God should do so, and the interpreter must therefore ensure that the particular text is interpreted in such a way as to harmonise with the whole. Paul and James emphasise different aspects of the single truth, but they are not permitted to disagree. Scripture is not a patchwork of diverse materials carelessly stitched together, it is the seamless garment of Christ, woven from top to bottom. What God has joined together, let no one put asunder.

In response, it is often said that this position is selective in its appeal to textual data, and that closer attention to the specificities of the biblical texts would result in a much more complex picture. ${ }^{3}$ At the heart of this position (it might be claimed), there lies not so much a 'scriptural doctrine of scripture' as a series of a priori deductions from the fundamental equation of scripture and Word of God. By contrast, a more a posteriori, inductive approach would give greater weight to the individual character of texts and genres, and thus to the mediated character of the divine Word. On this view, God does not address us directly in the text of, say, the Song of Solomon or the Epistle of Jude. Yet God intends to communicate with us in and through these texts, and each of them has its own particular contribution to make to the articulation of God's Word. Scripture is, no doubt, a seamless garment, but it is above all a coat of many colours. Its glory is its diversity, and to reduce it to a uniform shade of grey would be to diminish its rich apprehension of a God who always transcends and evades our categories and conceptual schemes. On this view, scriptural unity is no longer so directly correlated with a doctrine of inspiration. Instead, scriptural unity derives from a providential ordering of scripture that ensures that each part has its particular role in the divine self-communication. As with the

3 Thus John Goldingay raises the question how far a 'doctrine of scripture' using categories such as authority, revelation, inspiration, word of God, canon, infallibility, and inerrancy 'is itself scriptural', Models for Scripture (Grand Rapids: Eerdmans; Carlisle: Paternoster, 1994) p. 2. Such terms tend to underplay scriptural diversity, and it is this that we need to recover. 'To emphasize diversity in this way is not to deny a unity to scripture but to recognize that scripture is characterized by the richness of a living reality...' (p. 18). 
providential ordering of the world itself, there will not be outright contradiction but there may be very considerable difference. The different parts serve to maintain the balance of the whole, making it impossible to absolutise any one of the parts and to treat it as if it were itself the whole. For the sake of this providential balance, Paul needs James and Proverbs needs Qoheleth. Biblical polyphony should not be reduced to the monotony of a single voice.

The Bible is a seamless garment, or it is a coat of many colours. Its unity is grounded in the divine inspiration of all of its parts, so that it is straightforwardly and literally 'the Word of God'; or its unity is grounded in the providential ordering that ensures that each part makes its own indispensable contribution to the divine selfcommunication. There is much to be said for both of these views, which may differ from one another more in emphasis than in substance. Both views retain the fundamental correlation between the Bible and the reality of God-a correlation that has all but disappeared in so much contemporary biblical scholarship. Both views accept that the Christian community is the primary context for biblical interpretation, and that theological scholarship is answerable to that community. One view is more 'conservative', the other more accommodating towards the methods and findings of modern scholarship. But in both cases we have a 'high' doctrine of scripture as the unique embodiment of God's self-communication to humankind. 4

The only problem is that neither approach to scriptural unity can truly be said to be evangelical. In setting out the two positions, we have at no point been compelled to ask about the relation of scripture and gospel. But no theological position can be said to be evangelical in the absence of the evangelium. In brief, the problem with both approaches to scriptural unity is that they operate within the framework of a self-contained, foundational 'doctrine of scripture'. This doctrine traces the biblical texts back to an ultimate divine authorship, operating by way of 'inspiration' and/or providential ordering, and it reflects on the implications of this divine authorship for the character of the texts: their authority, their trustworthiness, their sufficiency, their relation to tradition and the church, and so on.

4 Both approaches are represented by contributors to The Trustworthiness of Our God (eds. Paul Helm and Carl Trueman; Grand Rapids: Eerdmans; Leicester: Apollos, forthcoming in 2001); see especially Donald Macleod, 'Jesus and Scripture', and Timothy Ward, 'The Diversity and Sufficiency of Scripture', together with my own response. 
Remarkably, however, this doctrine of scripture is almost entirely formal in character, and has little to say about the content or subjectmatter of the biblical testimony. The result is that God's action in relation to scripture is removed from its proper context within God's overarching, comprehensive action of reconciling the world to himself in and through Jesus, together with everything that leads up to it and that flows from it. It is, of course, precisely this divine action of which the gospel speaks. ${ }^{5}$

How, then, is biblical unity and coherence to be construed in the light of the gospel? At this point, we turn for guidance to Paul's letter to the Galatians; for in that text more than any other, the construction of a scriptural hermeneutic oriented towards the gospel is the primary concern. Our discussion will be focused on the terms 'gospel', 'law' and 'promise'.

\section{Gospel}

In Galatians, scriptural interpretation is contested. As they instruct the Galatian Christians in the observance of the law, Paul's opponents are also instructing them in the interpretation of a text. In 'desiring to be under law' (Gal. 4:21), the Galatians desire to conform their lives to a text, and to relocate their allegiance to Jesus within the matrix of that text. Paul too must therefore speak of Jesus in relation to the scriptural text. Everyone is agreed, it seems, in a 'high' view of scriptural

5 In my view, this 'formalism' is also evident in Nicholas Woltersdorff's attempt to rethink the concept of 'word of God' in the light of speech-act theory, Divine Discourse: Philosophical Reflections on the Claim that God Speaks (Cambridge: Cambridge University Press, 1995). According to Woltersdorff, the Bible may most naturally be understood as 'one book of God' if it is seen as 'divinely appropriated human discourse' (p. 53); the speech-act of 'appropriation' occurs in locutions such as 'I agree with that', or 'I second the motion' (p. 52). Not all of what is appropriated will itself be divine discourse (i.e. prophetic utterance), or even inspired. 'All that is necessary for the whole to be God's book is that all the human discourse it contains have been appropriated by God, as one single book, for God's discourse. If it is the Christian Bible we are speaking of, the event that counts as God's appropriating this totality as the medium of God's own discourse is presumably the rather drawn out event consisting of the Church's settling on the totality as its canon' (p. 54). Woltersdorff is critical of Karl Barth's attempt (Church Dogmatics, I/1, §4: 'The Word of God in its Threefold Form') to set the Bible as 'Word of God' in the wider context of the divine communicative action as a whole (Divine Discourse, pp. 63-74). For an attempt to show how Barth's model overcomes the formalism of the conventional equation of Bible and Word of God, see my contribution to The Cambridge Companion to Karl Barth, ed. John Webster (Cambridge: Cambridge University Press, 2000), pp. 57-71. 
authority. The text is God's Word, and, whether it speaks of law or of promise, it speaks the truth. The first text Paul cites is Gen. 15:6, and it is immediately followed by the imperative, 'Know then...'

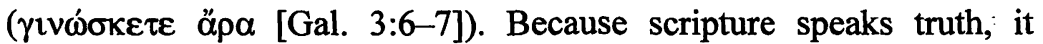
enables us not just to conjecture but to know. The second text, the divine promise that 'in you all the Gentiles shall be blessed' (Gen. 12:3), is presented as an utterance of scripture to Abraham: 'The scripture, foreseeing that by faith God would justify the Gentiles, preached the gospel beforehand to Abraham...' (Gal. 3:8). The voice of scripture is the voice of God, and the voice of God is the voice of scripture. Divine agency is also ascribed to scripture when it is said that 'the scripture shut up everything under $\sin . . . '$ (3:22). The promises speak of a singular 'seed' of Abraham, rather than of 'seeds' (3:16): major theological points may be derived from minor details of scriptural usage. The traditional formula 'it is written' suffices to establish a point $(3: 10,13,4: 22,27)$, since conformity to scripture is the guarantee of truth. It is inconceivable that Paul's opponents take a lower view of scripture than he does. They have every reason to insist that what scripture says God says, and that the scriptural text is to be regarded as the supremely authoritative and sufficient guide to conduct and belief. Yet it is precisely on the common ground of a high view of scriptural authority that a life-and-death struggle for the truth of the gospel is played out. Evidently there can be a high doctrine of scripture that radically misunderstands the gospel.

Paul devotes over a third of his letter to the theme of 'the gospel' before he cites his first scriptural text (3:6). That does not mean that he subordinates the written text to a spoken message; for Paul here testifies to the gospel by way of a written text of his own, whose claim to scriptural or proto-scriptural normativity is everywhere overwhelmingly evident. In fulfilment of his apostolic commission Paul writes as well as speaking (cf. 1:1). 'See with what large letters I write to you in my own hand' (6:11): Paul invites his addressees not only to listen as his text is read but also to subject his handwriting to a visual inspection. Even the semi-literate will find his large letters easy to read, and all will find in the physical appearance of his text an unambiguous illustration of its imperious claim to an authority that cannot be evaded. It is scripture itself - in the form of this Pauline writing - that articulates a scriptural hermeneutic oriented towards the gospel. 6

6 It is therefore a crude misstatement to claim that 'the time of the Bible was a time when the Bible was not yet there' (James Barr, Holy Scripture: Canon, 
And what is this 'gospel'? It is 'the gospel of Christ' (1:7), and it is 'of Christ' in the first instance because it speaks of Christ as the one 'who gave himself for our sins, to deliver us from the present evil age', just as it speaks of God as the Father whose fatherhood is enacted in the event of his raising Christ from the dead (1:1, 4; cf. Rom. 1:4). The gospel is the message about Christ, his death and resurrection, and about what all this means in relation both to God and to ourselves. It is a message that reaches $u s$-if we may set ourselves alongside the Galatians as co-addressees of this letter-through the spoken or written utterance of a fellow-human divinely commissioned to proclaim this message (cf. 1:1). This divine commissioning arises out of the event of Jesus' death and resurrection, and indicates that the event aims at its own recognition and acknowledgement, so that those who hear of it will henceforth live in the light of it. The close correlation between event and proclamation is confirmed by the fact that the same God is seen as active in both. Christ's giving of himself for our sins takes place 'according to the will of God' (1:4), and God is the one who 'raised him from the dead' (1:1); but God is also the one who initiates Paul's apostleship (1:1), and who, in and through Paul's preaching, 'called you in the grace of Christ' (1:6). It is just conceivable that Paul, or even an angel from heaven, might not truly preach the gospel (1:8-9). But insofar as he does so, his speech is God's speech. When Paul speaks to the Galatians of the grace of Christ, God calls them in the grace of Christ (1:7). In the proclamation of the gospel, it becomes clear that God's act in Christ is the definitive divine speech-act. The gospel is integral to God's self-communication to the world, since it gathers up the divine action into speech and enables it to fulfil its communicative intent. In the gospel, a past divine action is transformed into present divine speech, in accordance with its own innermost dynamic. In this transformation, the past does not cease to be the past. God's action and Christ's are spoken of by

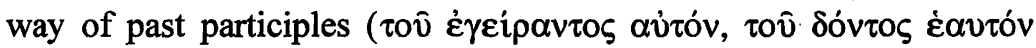
$[1: 1,4])$. Yet this past is not just an ordinary past, separated from the present by a temporal interval similar in kind to the four hundred and thirty years between the promise and the law, to which Paul will later refer (3:17). Unlike other pasts, this past has the power to impinge

Authority, Criticism, Oxford: Clarendon, 1983), p. 1. Barr asks: 'Did not the men of the New Testament live by personal contact and oral tradition rather than by submission to a written document?' (p. 22) 'Submission to a written document' is exactly what Paul requires of the Galatians, though not in abstraction from the 'personal contact' that the document itself enacts. 
directly on the present as it becomes the medium and content of the divine 'call', in and through preaching. Thus the Christ who is preached and the God who calls are themselves determined by the past actions in which Christ gave himself and God raised him from the dead-actions which constitute, finally and unsurpassably, the identity of God, Christ and world. To hear the gospel, as the Galatians once did, is to be the object of a divine speech-act that occurs in the present but also encompasses past and future. ${ }^{7}$

The gospel is not, therefore, what it might appear to be: a traditional account, handed down from generation to generation, about a series of straightforwardly past events in which God once acted. In that case, it would be a purely human task and obligation to keep alive the memory of those events. Paul, however, insists that God is no less directly involved in the gospel than in the raising of Jesus: the gospel

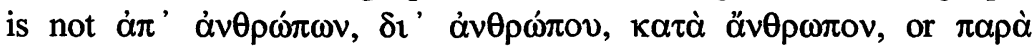
óv $\theta \rho \dot{0} \pi \mathrm{r}$ any more than the resurrection is $(1: 1,11,12)$. The divine agency and intentionality is one and the same in the two cases: just as there is no gospel without resurrection, so there is no resurrection without gospel. In the gospel, therefore, the radical priority of divine over human action is both confessed and enacted. Human agency is not simply eliminated, for the gospel is nothing without human speaking and hearing; yet human agency is always secondary to divine agency, dependent on it and enabled by it. This radical divine priority is illustrated by the life-story of Paul himself. As a free, selfdetermining human agent, he becomes a persecutor of the church in his zeal for the ancestral traditions (1:13-14). And yet from before his birth his entire life is enclosed within the scope of the divine grace and calling, so that there comes a moment when it is transformed by the revelation of God's Son, whom Paul is to preach among the Gentiles (1:15-16). Because his commissioning is from God, Paul is in no need of any further commissioning or instruction from any

7 This formulation recalls, but also differs from, Bultmann's claim that for Paul 'the salvation-occurrence is nowhere present except in the proclaiming, accosting, demanding and promising word of preaching', Theology of the New Testament, 1.302 (ET London: SCM, 1952), p. 302. 'God made this event [i.e. the historical event of Jesus' crucifixion at Golgotha] the eschatological occurrence, so that, lifted out of all temporal limitation, it continues to take place in any present moment, both in the proclaiming word and in the sacraments' (p. 303). For Bultmann, the pastness of the salvation-event is erased as this event becomes present. But then one form of 'temporal limitation' is merely exchanged for another: a purely present occurrence is no less temporally limited than a purely past one. Bultmann fails to take seriously the past tenses that Paul invariably uses in connection with the death and resurrection of Jesus. 
human source, although he does seek and obtain a human acknowledgement of this commissioning (1:16-2:10). Paul's relative independence from the Jerusalem church is of course not a proof of his divine call, but it does illustrate it and conform to it. It shows that the gospel remains in God's hands, and is not handed over to its human representatives-even if their names are Peter, James or John, who are reputed to be 'pillars'.

Since the gospel speaks of and participates in a divine action possessing final, eschatological validity, it is addressed to all, Jews and Gentiles alike. The whole world falls within its scope. As a sign of this, Jewish and Gentile Christians at Antioch share meals together-and are promptly opposed by those who do not share Paul's conviction that what has taken place in Christ is nothing less than a 'new creation' (6:15), and who seek instead to accommodate Christ to existing reality (2:11-14).8 Paul gives his own interpretation of what is at stake here in an antithesis between a justification 'by works of law' and one that is 'by faith of Christ' ( $\dot{\varepsilon} \xi \varepsilon$ है $\rho \omega v$ vó $\mu \mathrm{ov}$ [three

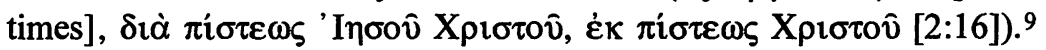

8 In his study of 'the Antioch Incident', J.D.G. Dunn notes three possible interpretations of the immediate issue, Jesus, Paul, and the Law: Studies in Mark and Galatians (Louisville: Westminster/John Knox; London: SPCK, 1990), pp. 129-82, esp. pp. 151-58. (1) The Antiochene church had completely abandoned the Jewish dietary code; (2) it practised the dietary code but not circumcision, which was therefore the issue here as it had been in Jerusalem; or (3) it practised the dietary code, but not as strictly as the 'men from James' would have wished. Dunn argues for the third option. However, table fellowship is linked with the

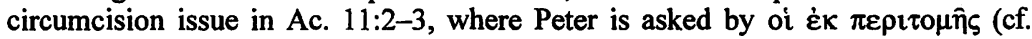

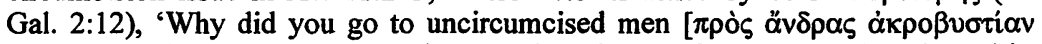

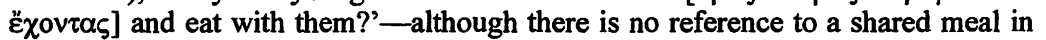
the narrative of Acts 10. We might therefore see in Ac. 11:3 a reminiscence of the 'Antioch incident', which, of course, Luke does not otherwise mention. Paul's

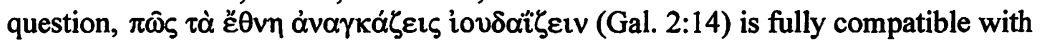
a reference to circumcision: cf. the use of the first verb in Gal. 2:3, 6:12 and of the second in Est. 8:17 LXX, Josephus, $B J$ ii.454-although neither verb necessitates a reference to circumcision. It is not clear that a demand for circumcision as a condition of full church membership need be incompatible with the limited agreement to which Gal. 2:6-10 refers; it might be understood as a necessary clarification. An advantage of this interpretation is that it relates the Antioch incident much more closely to the situation in Galatia-as well as explaining the otherwise gratuitous reference to circumcision in 2:12; so Philip Esler, Galatians (London/New York: Routledge, 1998), pp. 137-38.

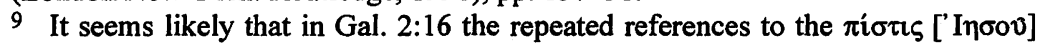

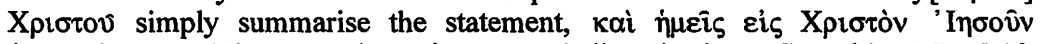

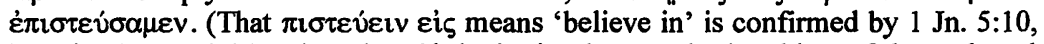
Ignatius Mag. 10:3.) Otherwise, Christ is simultaneously the object of the verb and the subject of the cognate noun: we believed in Christ Jesus, in order to be justified by Christ's own faithfulness. The shift in the roles the two phrases would then 
'Faith' and 'works' both stand for human actions. The human action that Paul calls $\pi$ i $\sigma \tau \varsigma \zeta$ is the secondary, responsive acknowledgement of the eschatological divine action in Christ that intends and enables it. Faith is the human action that confesses the radical priority of the divine action. It is a seeing and hearing in which attention is focused exclusively on the one seen and heard, the crucified Jesus Christ $(3: 1-2,5)$. 'Works of law', on the other hand, represents a mode of human action belonging to another context - that of 'living Jewishly' (2:14) - and that therefore fails to confess the divine priority in Christ.

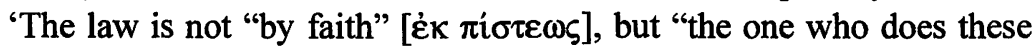
things shall live by them"' (Gal. 3:12, quoting Lev. 18:5 and referring back to Hab. 2:4). Paul's opponents at Antioch distort 'the truth of the gospel' $(2: 5,14)$ by asserting that a pattern of life prior to the gospel and independent of it remains normative for Jew and Gentile alike. They deny the comprehensive scope of what God has done in Christ, turning it into a supplement to an authoritative scripturally-grounded tradition that is left intact. For them God is the God of Moses and Jesus: the two figures exist on the same plane.

If the gospel speaks of and participates in the comprehensive, eschatological reality of the new creation, then this will radically affect the way that the scriptural texts are read. These texts are no less important to Paul than they are to his opponents. But, he argues, they are not to be read in abstraction from the gospel, as though God's act in Christ lacked its final and comprehensive scope. Scripture must be read in such a way as to draw out its testimony to the gospel, and it is the aim of the central section of Galatians to show in outline how this might be done.

\section{Law}

In Galatians 3, Paul's sketch of an evangelical hermeneutic presents scripture as determined by two antithetical principles, promise and

ascribe to Christ is awkward, though not impossible. Together with the variant $\delta i \dot{\alpha}$

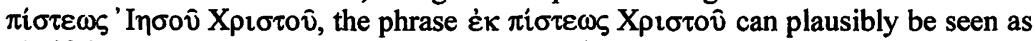

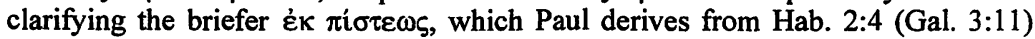
and uses with apparent reference to the faith of believers, not of Christ (Gal. 3:7, 8, 9; cf. 3:22, 24). Gal. 3:6-9 also suggests that the Pauline bias away from the verb (v. 6, quoting Gn. 15:6) and towards the noun (vv. 7, 8,9) does not entail the semantic shift that the subjective genitive reading must postulate in 2:16. Pace J.L. Martyn (Galatians, New York: Doubleday, 1997), p. 271, I do not believe that Paul's stress on the radical priority of God's apocalyptic act in Christ can only be safeguarded by way of the subjective genitive reading. 
law. Law is associated with certain specified forms of human action, promise with a divine speaking that anticipates a future divine action. In Paul's view, his opponents elevate law above promise in their emphasis on 'works of law'. Paul in contrast elevates promise over law, divine action over human; an evangelical hermeneutic is set over against a nomistic one. Yet this gospel-oriented hermeneutic must prove itself in the field of scriptural interpretation. If it results in forced, arbitrary readings, it will have failed to show that the gospel itself speaks of events that took place 'according to the scriptures'. One would then have to concede scripture to Paul's opponents, allowing gospel and scripture to go their separate ways. In unevangelical readings of scripture, it is assumed that Paul's first critics were basically right, and that the Pauline stress on the radical priority of God's action in Christ is just a personal idiosyncrasy that cannot be made plausible and fruitful for scriptural interpretation. Acting on that assumption, contemporary Old Testament or 'Hebrew Bible' interpretation rarely feels a need to draw upon Pauline hermeneutical insights.

Interpreters of these texts may claim that the results of Pauline exegesis do not inspire confidence in Paul as an exegete. According to Deuteronomy, those who do not continue to observe everything written in the book of the law are subject to God's curse. According to Paul, quoting this text in support, it is 'those who are of works of law'-those who strive to observe the law-who are under God's curse (Gal. 3:10, Dt. 27:26). A curse directed against law-breakers is converted into a curse against law-observers. If it is the logic of Paul's gospel that determines this apparently dubious exegesis, then the gulf between gospel and scripture may be too wide for any 'evangelical hermeneutic' to bridge. Does Paul simply impose his Christian convictions on scriptural texts, reading them 'against the grain' and forcing them to serve his own theological and polemical agenda? Perhaps those in quest of a credible evangelical hermeneutic would do well to avoid Galatians? ${ }^{10}$

10 As Brevard Childs puts it: 'How is one to evaluate a usage which appears to exercise such an incredible freedom toward the Old Testament text as to disregard almost entirely attention to its original context and meaning?', Biblical Theology of the Old and New Testaments (London: SCM, 1992), p. 238. 'A basic obstacle for the modern interpreter of Paul lies in his not recognizing the Old Testament as having a voice separate from that of the New Testament' (p. 242). It is 'the responsibility of the church... to seek to hear the voices of both testaments, which for Paul were not distinguished' (p. 244). It seems to me that a coherent biblical theology of both testaments will be unattainable so long as the New Testament's use of the Old is construed negatively, merely as a problem to be overcome. 
Problems on the surface of Paul's texts are often an expression of an underlying theological logic that merits close attention; and that is the case here too. In the example selected, an individual verse is cited in order to illustrate the fundamental dynamic of Jewish scripture as caught in a tension between law and promise, human and divine agency. Here and elsewhere, Pauline exegesis is concerned not just with the individual text but with the entire scriptural complex of which it is an expression. We will attempt to uncover the theological logic that determines Paul's use of texts from Deuteronomy and Genesis, and to show this to be a compelling and plausible evangelical logic.

Those who are of works of law are under a curse: why does Paul want his Deuteronomy text to confirm this conclusion? The conclusion is deduced from the gospel's fundamental affirmation that God's saving action in the death and resurrection of Christ is comprehensive in its scope and radically prior to the responsive human action that it intends, the act of faith that acknowledges the divine saving action and reorients the whole of life around this acknowledgement (cf. Gal. 2:20). There is, however, another scripturally-grounded way of life that is said to conform to the will of God, the way of life summed up in the phrase 'works of law'. In Paul's view, as we have seen, this way of life is the denial or evasion of God's eschatological and comprehensive saving action. It places human action in the foreground, not divine: thus, 'the law is not of faith...' (3:12). For Paul, this pursuit of a mode of human action in conformity with the revealed will of God cannot achieve what it hopes to achieve, the responsive divine affirmation, because it has been overtaken by an unconditional divine affirmation that is not determined by any prior human agency. The curse that the law is said to pronounce on those who are of works of law is, in Paul's mind, the law's own acknowledgement that its foregrounding of human action is in fact a dead-end. Insofar as it acknowledges this, the law bears witness to the gospel in drawing out its negative corollary. Since God has in Christ taken the human situation so entirely into his own hands and made it his own responsibility, humans are relieved of the burden of responsibility for their own eternal destiny-a burden that they are quite unable to bear, even when they encounter it in the form of the law of God. ${ }^{11}$

11 The radical priority of God's apocalyptic act in Christ is the central theological emphasis in J.L. Martyn's Galatians commentary (see, e.g., pp. 95-105). In spite of indebtedness to E. Käsemann at this point, Martyn does not follow Käsemann 
That is why Paul wants his text from Deuteronomy to testify that all who are of works of law are under a curse: not to serve the requirements of an ad hoc polemic but to testify indirectly to a saving divine action that has once for all closed the door on actions in which humans undertake responsibility for their own destiny. The law echoes the gospel's verdict, which is that all such projects are futile. At least, that is what Paul claims. But has he forced the law to say something it does not actually say?

The text from Deuteronomy is the last of a series of twelve curses which are to be proclaimed by the Levites when the people passes over the Jordan and arrives at Mount Gerizim and Mount Ebal (Dt. 27:11-26). Apart from the final one, these curses are directed against specific forms of behaviour: several are closely related to the decalogue $(27: 15,16,24$ : idolatry, dishonouring of parents, murder), while others refer to a range of sexual offences (27:20-23). The concluding curse summarises all the others: 'Cursed be the one who does not confirm the words of this law by doing them' (27:26). It is certainly not those who practise works of the law who are under this curse. Yet in the wider context of the concluding chapters of Deuteronomy things are not so simple. In these chapters, the curse that is initially directed against law-breakers is extended so that it encompasses all Israel. Up to this point, there has been no suggestion

and the Lutheran tradition in finding indirect negative testimony to 'justification by grace alone' in the impossibility of justification by works of law. That is, he does not regard 'grace' and 'works' as abstractly antithetical principles, the one asserting that God alone can save, the other proclaiming the possibility of human self-salvation. For Martyn, 'grace' and 'works' stand for an entirely concrete contrast between God's apocalyptic invasion of the world in Christ, on the one hand, and the imposition on Gentile Christians of certain Jewish practices and ideologies, on the other. To construe Paul's account of justification as a polemical doctrine directed against human attempts to 'earn salvation', to 'achieve salvation by one's own efforts', is therefore to misread him (see pp. 260-63). In the reading I offer here, the claim that 'works of law' represents a scriptural hermeneutic means that the particularity of Jewish practices and beliefs cannot be sacrificed to an abstract principle. Nor is it the case that oi ह̇k $\pi i \sigma \tau \varepsilon \omega \varsigma$ speak exclusively of a

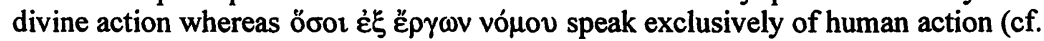
Gal. $3: 7,10$ ); both sides have their own distinctive ways of relating divine and human action. Nevertheless, it remains true that the human action Paul calls $\pi i \sigma \tau \varsigma \varsigma$ has Christ's eschatological action (or God's eschatological action in Christ) as its

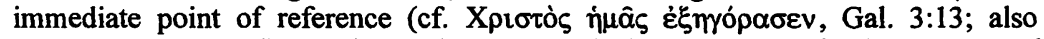

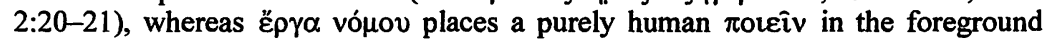
(cf. $3: 10,12$ ). The quest for righteousness by works of law represents a reading of Israel's scriptures in which ultimate well-being is dependent on a certain type of human action. In a forthcoming work on Pauline theology, I hope to clarify the relationship between a theological reading of Paul along these lines and the socalled 'new perspective on Paul'. 
that the people will inevitably fail to do what Yahweh requires of them, which is 'to fear Yahweh your God, to walk in all his ways, to love him, to serve Yahweh your God with all your heart and with all your soul, and to keep the commandments and statutes of Yahweh' (Dt. 10:12-13). This is the language of exhortation, not of judgement, and it presupposes that 'this commandment which I command you this day is not too hard for you, neither is it far off... The word is very near you; it is in your mouth and in your heart, so that you can do it' $(30: 11,14)$. If the people maintains its vigilance and learns from its former mistakes, a bright future awaits it in the land of promise. And yet the curse on all law-breakers (27:26) heralds the intrusion of prophetic denunciation into the context of priestly instruction and exhortation. The twelve curses of Deuteronomy 27:15-26 are prefaced by the words, 'And Moses charged the people the same day, saying...' (27:11), and this same speech of Moses continues until the end of Deuteronomy 28, without a break. In this lengthy chapter, an exposition of the blessings consequent upon obedience (vv. 1-14) is far outweighed by the exposition of the curses that will befall a disobedient nation (vv. 15-68). The conditional clause with which this long section opens ('If you will not obey the voice of Yahweh your God...') is repeated only once (v. 58); everywhere else it appears that the curses of plague, famine, defeat and exile are an inevitable fate corresponding to an inevitable disobedience. 'All these curses shall come upon you and pursue you and overtake you, till you are destroyed, because you did not obey the voice of Yahweh your God, to keep his commandments and his statutes which he commanded you' (v. 45). Here, 'because you did not obey' takes the place of 'if you do not obey', as priestly warning gives way to prophetic denunciation. ${ }^{12}$

A similar shift occurs in Moses' next speech (Dt. 29:1[28:69]-30:20). The possibility that an individual, a family or a tribe will turn from Yahweh to idols rapidly escalates into a wholesale devastation of the land, rightly interpreted by neutral observers as a judgement on national apostasy: 'It is because they forsook the covenant of Yahweh, the God of their fathers... [that] Yahweh's anger was kindled against this land, bringing upon it all the curses written in

12 This differentiation between 'priestly' and 'prophetic' perspectives in Deuteronomy coheres well with Robert Polzin's attempt to identify a plurality of 'voices' within this text, over against a 'monological' reading, Moses and the Deuteronomist: A Literary Study of the Deuteronomic History, Part One (Bloomington and Indianapolis: Indiana University Press, 1980). 
this book' (29:25-27). In this speech, however, the possibility of a restoration after exile is acknowledged (30:1-10), and the conditional note returns at the end (30:15-20). Finally, the "Song of Moses' is composed in the grim certainty that the people will turn away from Yahweh to the idols, so that when that time comes 'this song shall confront them as a witness (for it will live unforgotten in the mouths of their descendants)' (31:21). In the Song itself, it can already be said that 'they have dealt corruptly with him, they are no longer his children because of their blemish; they are a perverse and crooked generation' (32:5). On the eve of their entry into the promised land, Israel is already subject to the divine judgement. Not only the Song of Moses but the whole book of Deuteronomy stands as a written testimony against the entire people. 'Cursed be the one who does not confirm the words of this law by doing them' (27:26): this has become a statement about Israel. ${ }^{13}$

In the closing chapters of Deuteronomy, prophetic denunciation destabilises the priestly exhortation. According to the exhortation, the law should be and can be obeyed. According to the denunciation, Israel's disobedience makes divine judgement inevitable. Precisely this tension is writ large over the whole Old Testament. God has placed the future of the covenant in human hands, setting before his people life and death, blessing and curse (Dt. 30:19). And yet, again and again, the way of death and the curse is chosen rather than the way of life and blessing. Is Israel really capable of choosing the way

13 According to Martin Noth, Dt. 27:9-10, 28:1-68, and 30:15-20 represent the basic stratum in the final speeches of Deuteronomy; this was augmented first by $30: 1-14$, and then by 27:1-8, 27:11-26 and 28:69-29:28, The Deuteronomistic History (ET of second edition, Sheffield: Sheffield Academic Press, 1991), p. 33. If the curses of 27:15-26 ever formed an independent unit, its meaning and significance is altered by insertion into a context in which the divine curse becomes the key to Israel's entire covenant history. That Paul reads Dt. 27:26 within this broad context is confirmed by his substitution of rô.ov tois

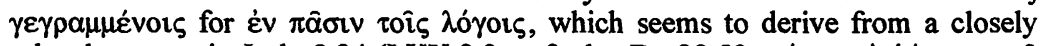

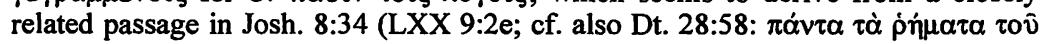

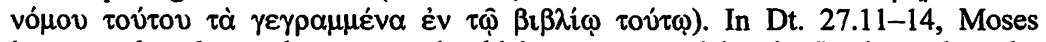
instructs that the twelve curses should be pronounced by the Levites when the people have entered the land and have come to Mounts Gerizim and Ebal, and the account of the fulfilment of his instructions in Jos. 8:30-35 already sets these curses in the context of the Mosaic law as a whole. After the Levites 'blessed the people of Israel' (a euphemism for pronouncing the curses?), Joshua 'read all the words of the law, the blessing and the curse, according to all that is written in the book of the law' (Josh. 8:34: MT, ככל־התוב בספר התורה; LXX [Josh. 9:2e],

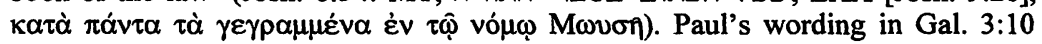
suggests that he understands the Deuteronomy text in the light of the Joshua passage. 
of life and blessing? Or is Israel so entangled in the way of death and curse that the only hope is that God will take his people's future out of their hands and into his own? The Old Testament texts do not offer any final resolution of this dilemma. ${ }^{14}$ According to Paul, that eschatological resolution has now taken place, beyond the world of these texts. In the gospel it is disclosed that God in Christ has assumed total responsibility for the future and that any attempt to retain that responsibility in human hands is futile, self-defeating and out of date. All this has taken place 'according to the scriptures', and Paul can therefore appeal to the testimony of the law, which 'confined everything under sin, so that the promise by faith of Jesus Christ might be given to those who believe' (Gal. 3:22). The law, which appeared to place the future of the covenant in human hands, in fact serves as a witness to human incapacity for this role. ${ }^{15}$

\section{Promise}

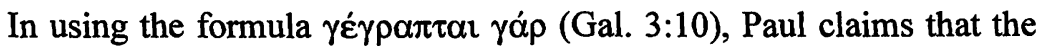
logic of his gospel conforms to the logic of scripture, and we have seen that his claim is not unfounded. Understood in the light of the gospel of Christ, scripture itself attests the futility of the false gospel of works of law. But scripture is not only law, it is also promise; indeed, it is promise before and after it is law. Paul must respond to the law-centred hermeneutic of his opponents, but scripture's testimony to God's eschatological saving action is for him more fundamental than its testimony to human incapacity. The positive and the negative sides of the scriptural testimony belong together and serve to confirm each other, but they are not of equal importance. The law's exposure of human incapacity must be clearly understood, but it must be kept in proportion. Paul does not direct his readers' gaze

14 The scriptural dilemma is clearly recognised in 4 Ezra 7:127-30, where Uriel replies as follows to Ezra's lament over the prospect of near-universal condemnation: 'This is the meaning of the contest which everyone born on earth shall wage, that if he is defeated he shall suffer what you have said, but if he is victorious he shall receive what I have said. For this is the way of which Moses, while he was alive, spoke to the people, saying, "Choose for yourself life, that you may live!" [cf. Dt. 30:19] But they did not believe him, or the prophets after him, or even myself who have spoken to them.'

15 My interpretation of Gal. 3:10 as referring the Deuteronomy text to Israel's entire covenant history is indebted to N.T. Wright, The Climax of the Covenant: Christ and the Law in Pauline Theology (Edinburgh: T. \& T. Clark, 1992), pp. $140-41$. 
equally to divine grace and to human sin, he sets before their eyes only the crucified Christ as the embodiment of God's grace (cf. 2:21-3:1). 'Where sin increased grace abounded all the more' (Rom. 5:20): the disproportion of sin and grace is a basic axiom of Pauline theology. Scripture, therefore, is supremely promise. It does not possess its centre within itself, for its fundamental testimony is to a divine future that lies beyond its own horizons. When scripture speaks in its most authentic voice, it proclaims the gospel in advance-as when Abraham was told, 'In you shall all the Gentiles be blessed' (Gal. 3:8). ${ }^{16}$

Rereading the Genesis narratives in the light of his gospel, Paul is impressed above all by the unconditionality of God's promise to Abraham. Abraham is not offered a choice between life and death, blessing and curse; he is not exhorted to choose the one way and warned of the dire consequences of the other. There are no contractual statements that make divine action contingent on the satisfactory performance of the human covenant-partner. There is simply a series of unqualified promises. It is true that God issues commands as well as promises, and that Abraham obeys these commands (cf. Gen. 12:1, $15: 1,17: 1,10-14)$. But in the absence of conditional statements, it seems that Abraham's obedience is enabled by the divine promise itself. The promise frees him to act in ways that would not otherwise occur to him, and it does so as he believes it, acknowledging it as what it truly is, the unconditional promise that commits God to future action on Abraham's behalf (cf. Gen. 15:1-6). ${ }^{17}$ There is nothing

16 Paul's attribution of the law to angels (Gal. 3:19; essential to the arguments of $3: 15-18,20,4: 9-10)$ is an attempt to express this secondariness of law in relation to promise. Within the divinely ordained limits of their authority, bounded on one side by the promise and on the other by its fulfilment, the angels' decrees are fully valid (cf. Gal. 3:10,12,13,22) and in no sense contrary to the promises of God (3:21). Although this argument is not repeated in Romans, comparable attempts are made to subordinate law to promise by distancing the law from divine agency (cf. Rom. 4:15, 5:20, 7:9, where agency is ascribed to the law itself-and, in the last case, to $\sin$ ). It becomes clear that even in Galatians Paul does not really 'anticipate Marcion' (contra Martyn, Galatians, p. 365) when one traces his statements back to their fundamental, evangelical rationale. Although the law remains the law of God (Rom. 7:22), the crucial point for Paul is that Sinai is no longer the privileged site of definitive divine self-disclosure (cf. Gal. 4:24-25). God is the one who raised Jesus Christ from the dead (Gal. 1:1): it is in the death and resurrection of Jesus - and not at Sinai - that the divine identity is definitively disclosed. As 'promise', scripture looks ahead to the event in which God is, supremely and definitively, who God is. It also does so as law-but negatively and indirectly.

17 It is true that, on two occasions, the promises are connected to Abraham's prior obedience. In Gn. 22:15-18, the promises are confirmed to Abraham 'because you 
especially meritorious about this believing of God's promise. It is integral to the speech-act of making a promise that the promise should be credible to its recipient; the promise must be made in such a way as to ensure its own credibility. God, therefore, is responsible for the fact that Abraham regards his promise as credible. A promise also creates a relationship between two parties, who are henceforth bound together by the commitment of one to future action on behalf of the other. That is why Abraham is 'reckoned righteous' when he believes: not because he has successfully fulfilled an arbitrary condition for obtaining the divine favour, but because he is enabled to live within the relationship that the promise has opened up. His 'righteousness' is his acceptance of the promise. 18

have done this, and have not withheld your son...', 'because [רש עקב you have obeyed my voice' (vv. 16, 18). In Gn. 26:5, the promises are confirmed

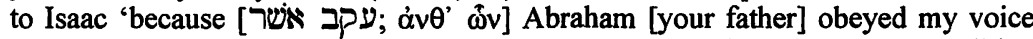
and kept my charge, my commandments, my statutes and my laws'. The addition of 'your father' in Gn. 26:5 LXX further underlines the close links between the two passages. C. Westermann comments on Gn. 22:15-18: 'The promises to the fathers are, in essence, free assurances by God. To ground them, as here, on Abraham's achievement is to alter the understanding of them. The Deuteronomic theology with its conditional promise is presupposed', Genesis 12-36: A Commentary (ET London: SPCK, 1986), p. 363. As for 26:5, 'Abraham is here the exemplar of obedience to the law in return for which God bestowed the promises on him; this can have been pronounced and written only in a period when Israel's relationship to God was centered on its obedience to the law', i.e. in 'the postDeuteronomic period, as the language of v. 5 clearly shows' (pp. 424-25). Whether or not one adopts a diachronic explanation along these lines, the two passages appear to be out of keeping with the assumption elsewhere that the promise stems solely from the free divine initiative, which Abraham can only follow. If $\mathrm{Gn} .22: 15-18$ is taken at face value, God jeopardises the promises in the testing of Abraham-not by commanding the sacrifice of Isaac but by making the promises dependent on Abraham's willingness to carry. out this action. Would the promise have been cancelled if Abraham had not proved faithful, despite earlier unfaithfulness in Gn. 12 and 16 ? There is nothing in the initial testing motif $(22: 1)$ to suggest that Abraham will forfeit the promises if he refuses the divine commandment. It is noteworthy that Paul does not discuss Gn. 22-unlike James, for whom it demonstrates that Abraham was justified by works, thereby bringing

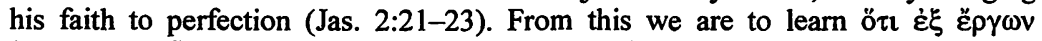

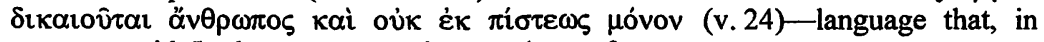
company with Luther, one can only regard as unfortunate.

18 According to G. von Rad, the language of 'reckoning' righteousness is drawn from the sphere of the cult, where the priest formally pronounces a particular cultic state-of-affairs such as the valid performance of a sacrifice, The Problem of the Hexateuch and Other Essays (ET Edinburgh and London: Oliver \& Boyd, 1966), pp. 126-27, citing Lv. 7:18b, 17:4, Nu. 18:27. Whereas "the cultic "reckoning" depended on something done by the human worshipper, by way of sacrifice or specific obedience', in Gn. 15:6 'it is laid down that it is faith which sets men on a right footing with God...' - the faith that takes the form of acceptance of Yahweh's 
Like Abraham's faith, Christian faith is evoked by God's word: the word of promise in the case of Abraham, the announcement of the fulfilment of the promise in the case of those who believe the gospel. The word of promise is therefore an anticipation of the word of the gospel. What was once announced as purely future is now declared to have been fulfilled, in an eschatological action that comprehends past, present and future. God's unconditional commitment to Abraham is at the same time an unconditional commitment to the whole of humankind: 'In you all nations shall be blessed' (Gn. 12:3, quoted in Gal. 3:9). In speaking as he does to Abraham, God assumes nothing less than total responsibility for humankind's ultimate well-being. It is not surprising, then, that in all this Paul hears scripture preaching the gospel to Abraham (Gal. 3:8). There is an exact correlation between the eschatological divine saving action announced by the gospel and the unconditional commitment given to Abraham. Paul does not speak of Abraham with reluctance, compelled to do so by the fact that this figure is high on his opponents' agenda. (His opponents certainly advocated works of the law, and specifically circumcision, but the role of Abraham in their gospel is a matter of conjecture.) Abraham is the key figure in Paul's attempt to show that an evangelical hermeneutic offers a more persuasive reading of scripture than a nomistic one. 19

This evangelical hermeneutic is especially attentive to certain scriptural antinomies, one of which has already been noted. On the one hand, scripture places responsibility for ultimate well-being in human hands; it teaches that 'the one who does these things shall live by them' (Gal. 3:12, quoting Lev. 18:5). On the other hand, scripture also suggests that every attempt to exercise this responsibility will end in disaster (cf. Gal. 3:10); an unconditional divine saving action is the only hope for humankind. A second, closely related scriptural antinomy arises out of Paul's reflections on the Abrahamic promises, and he states the issue as follows: 'The law, which came four hundred and thirty years afterward, does not nullify a covenant previously

plan for the future (p. 129). The faith that constitutes righteousness before God is itself oriented towards God's word and action.

19 J. Sumney challenges the scholarly consensus that Abraham was a key figure in Paul's opponents' message, which he claims derives from a methodologically dubious 'mirror reading' of Paul's own statements, 'Servants of Satan', 'False Brothers' and Other Opponents of Paul (Sheffield: Sheffield Academic Press, 1999), pp. 154-55. If the opponents linked their demand for circumcision to the figure of Abraham, it is hard to see how Paul can confine his reference to Gn. 17 to a single brief allusion (Gal. 3:16, cf. Gn. 13:15, 17:8). 
ratified by God, so as to make the promise void. For if the inheritance is by the law, it is no longer by promise; but God gave it to Abraham by a promise' (3:17-18). In the promise, God assumes unconditional responsibility for the final well-being of humankind. In the law, or so it might seem, that responsibility is transferred into human hands. If that is really the case, what becomes of the unconditional commitment made to Abraham? Has God changed his mind, revoking his promise and making his future action conditional on a prior human action? It is crucial to note that this is not a difficulty invented by Paul for purposes of his own: once pointed out, it is clearly recognisable in the Pentateuchal texts themselves. ${ }^{20}$ One attempt to resolve the dilemma is proposed by the author of Jubilees, who turns Abraham into an outstanding if premature example of obedience to the law, richly deserving of God's blessing. Paul's solution is the exact opposite of this projection of a nomistic perspective onto the Genesis narratives. $\mathrm{He}$ insists that the unconditional divine promise still stands, and that responsibility for ultimate human well-being is still God's and has not been transferred into human hands. What then is the significance of the law, which seems to assume that some such transfer has indeed taken place? The answer, which Paul heard in the closing chapters of Deuteronomy, is that the law exposes human incapacity for any such responsibility. In so doing, it bears its own negative witness to the unconditional divine saving action promised to the whole world in Abraham and actualised in Jesus' death and resurrection.

\section{Conclusion}

In order to grasp the radical priority and the comprehensive scope of what God has done in Jesus, it is essential to recognise that God has assumed responsibility for our situation and that responsibility is therefore taken out of our own hands. Scripture, both as promise and

20 Thus, R. Polzin finds here an instance of the reinterpretation and revision of older tradition. 'The overriding voice of the Book of Deuteronomy is against an immutable orthodoxy that would petrify the living word of God... If the terms of the covenant God made with the Israelites at Horeb are subject to revision at least in the sense of subsequent interpretation, then the same has to be said about the promise God made to our fathers. This promise made to the elect of Israel must not be so unconditionally understood that it provides a rigid guarantee of mercy in the face of widespread disobedience of God's law' (Moses and the Deuteronomist, p. 67). For Paul as for the author to the Hebrews (Gal. 3:15-18, Heb. 6:13-20), it is precisely the immutability of the promise that constitutes it as 'the living word of God', or rather, as the word of the living God. 
as law, enables Paul to clarify this point and so to demonstrate that his gospel is not an idiosyncratic invention of his own but is truly 'according to the scriptures'. The gospel accords with the scriptures only when the scriptures are read or reread in the light of the gospel. But this rereading must show itself to be, in broad outline, a plausible interpretation of the fundamental dynamics of the divine-human relationship as attested in scripture. If Paul can only read scripture 'against the grain', then he has lost the argument with his opponents. His task, and ours too, is to show that a genuinely evangelical hermeneutic can offer a richer, more nuanced and more coherent reading of scripture than any of its unevangelical rivals. 